\title{
Yield and Quality of Creeping Bluestem as Affected by Time of Cutting
}

\author{
R.S. KALMBACHER, F.G. MARTIN, AND J.M.S. ANDRADE
}

\section{Abstract}

Creeping bluestem (Schizachyrium stoloniferum Nash.) is a rhizomatous native grass that is the dominant species on many Florida rangelands. To evaluate its grazing potential, dry matter yield, in vitro organic matter digestibility (IV OMD), crude protein, neutral detergent fiber (NDF), acid detergent fiber (ADF), and acid detergent lignin (ADL), were measured in plants cut at 10 and 20 cm stubble heights during 70-day intervals from June to October (summer), August to December (summer-fall), and October to February (winter). Winter yields were significantly greater $(2,090$ $\mathrm{kg} / \mathrm{ha}$ ) than summer yields $(1,600 \mathrm{~kg} / \mathrm{ha})$ with summer-fall yields intermediate $(1,860 \mathrm{~kg} / \mathrm{ha})$. After 3 years there was a significant decline in dry matter in plants cut at $10 \mathrm{~cm}$, but yield was sustained in plants cut at $20 \mathrm{~cm}$. Herbage regrowth in July to August was high in IVOMD (37.8\%). Crude protein and IVOMD percentages were also greater in November to December regrowth $\mathbf{7 . 5}$ and $36 \%$, respectively) and January to February regrowth (6.8 and $37 \%$, respectively). However, since forage yield was lowest at the time, yield of protein and digestible organic matter were lowest. Percent NDF, ADF, and ADL were not greatly affected by initial growth or regrowth periods and averaged $80.0,42.3$ and $5.8 \%$, respectively. Creeping bluestem may be one of Florida's greater yielding native grasses, but will require protein and energy supplements to provide good livestock performance.

Creeping bluestem (Schizachyrium stoloniferum Nash.) is a warm-season, rhizomatous perennial grass (Yarlett 1970), and its dominance on Florida (Yarlett 1963), Georgia, and Alabama (Halls et al. 1964) flatwoods range makes the species among the most widespread and desirable of Southern native grasses. It responds favorably to range improvement and increases pasture yield above that of wiregrass (Aristida stricta Michx.) dominated range. Yarlett (1965) estimated that green weight yields of creeping bluestem increased from $1,800 \mathrm{~kg} / \mathrm{ha}$ at 3 months after mechanical brush control to $6,700 \mathrm{~kg} /$ ha at 11 months after treatment.

Creeping bluestem was found to out-yield four other native grasses in an investigation by Roush and Yarlett (1973). Time, frequency, and height of cut were found to affect yield and vigor. Lowest yield (12 metric tons/ha of green forage) resulted from cutting at $10 \mathrm{~cm}$ above the soil whenever the plant reached $20 \mathrm{~cm}$ in height. Greatest yicld ( 21.5 metric tons/ ha) resulted from harvesting $50 \%$ of the plant in April, June, and September. These yields reported by Roush and Yarlett were high because all grasses received fertilization.

The major contribution that creeping bluestem can make in a grazing program results from its forage production potential. Cattle can have a 5 to 6-month grazing period as compared with 1 to 2-month period with other native forage resources.

Crude protein and in vitro dry matter digestibility (IVDMD) of a composite of several bluestems, including creeping bluestem,

\footnotetext{
Authors are associatc agronomist, Ona Agricultural Research Center, Ona, Florida 33865; associate statistician University of Florida, Gainesville 32611; and pasture researcher, EPAMIG, Dept. Fitotecnia, Minas Gerais, Brazil.

This report is Florida Agr. Exp. Sta. Pap. No. 2156.

Manuscript received January 2, 1980.
}

were reported by Lewis (1975). In April forage averaged 10.2\% protein and $54.0 \%$ IVDMD, but declined to $3.2 \%$ protein and $34.0 \%$ IVDMD by October.

In order to evaluate the potential of creeping bluestem, additional information is needed about its seasonal yield and quality. This investigation was designed to determine the dry matter yield, in vitro organic matter digestibility (IVOMD), crude protein, neutral detergent fiber (NDF), acid detergent fiber (ADF), and acid detergent lignin (ADL) in plants cut at 10 and $20 \mathrm{~cm}$ above the soil during 70-day intervals from June to October, August to December, and October to February.

\section{Materials and Methods}

Experimental work was conducted at the University of Florida's Ona Agricultural Research Center which is $27^{\circ} 55^{\prime} \mathrm{N}$ and $81^{\circ} 55^{\prime} \mathrm{W}$. The soil was unlimed, unfertilized Immokalee fine sand, which is an Arenic Haplaquod. From samples taken in the upper $15 \mathrm{~cm}$, soil $\mathrm{pH}$ was 4.0 , and inherent soil $\mathrm{P}$ was $6.0 ; \mathrm{K}, 75.0 ; \mathrm{Ca}, 550.0$; and $\mathrm{Mg}$, $165.0 \mathrm{~kg} / \mathrm{ha}$.

A thick stand of creeping bluestem, which had not been burned during the 3-years prior to its selection in 1975 , was cut to $10 \mathrm{~cm}$ and all forage removed in early January, 1976. The experiment was designed as a split-plot with whole plots arranged in four randomized, complete blocks. There were three whole plots which were time of clipping or sampling: June to October; August to December; and October to February. Each whole plot was cut three times per year: at the beginning of each period (June, August, October) and twice thereafter on approximately 70 -day intervals. The initial growth refers to forage accumulated between the third or last cutting (ie. October) and the first cutting (ie. June), and regrowth refers to the forage produced in the two, 70-day intervals after the initial harvest. Sub-plots were height of cutting above the soil, and plots, which were $1.5 \times 5.0 \mathrm{~m}$, were cut at 10 and $20 \mathrm{~cm}$ with a rotary-type harvester.

Yield and dry matter were calculated from fresh sub-samples of approximately $0.25 \mathrm{~kg}$, dried at $60^{\circ} \mathrm{C}$. Methods desribed by Gallaher et al. (1977) and Isaac and Johnson (1976) were used for nitrogen analysis and that of Moore et al. (1972) for IVOMD. Yield of digestible organic matter (DOM) was calculated by multiplying dry matter yield by both IVOMD and organic matter percent. NDF, ADF, and ADL were determined according to the procedure described by Van Soest (1963) and Van Soest and Wine (1967).

\section{Results and Discussion}

\section{Dry matter yield}

Forage yield from June to October of 1978-79 was significantly lower $(P<0.05)$ than the yicld of the previous 2 years (Table 1$)$. There was no significant drop in yield in the third year when creeping bluestem was clipped in August to December or October to February. When time of clipping was examined within 1976-77 and $1977-78$, it was found that production resulting from cutting 
Table 1. Annual dry matter yield ( $\mathrm{kg} / \mathrm{ha}$ ) of creeping bluestem as affected by year and time of clipping. Ona, Florida, 1976-79.

\begin{tabular}{|c|c|c|c|c|}
\hline \multirow[b]{2}{*}{ Year } & \multicolumn{3}{|c|}{ Clipping period } & \\
\hline & June to $\mathrm{O}$ & g. to $\mathrm{D}$ & ct. to Feb. & \\
\hline $\begin{array}{l}1976-77 \\
1977-78 \\
1978-79\end{array}$ & $\begin{array}{l}1670^{\mathrm{a} 11} \\
1790^{\mathrm{a}} \\
1350^{\mathrm{b}} \\
\end{array}$ & $\begin{array}{l}1900^{\mathrm{a}} \\
1950^{\mathrm{a}} \\
1740^{\mathrm{a}} \\
\end{array}$ & $\begin{array}{l}1930^{\mathrm{a}} \\
2150^{\mathrm{a}} \\
2180^{\mathrm{a}} \\
\end{array}$ & $\begin{array}{l}b, a b, a^{2} \\
b, a b, a \\
c, b, a\end{array}$ \\
\hline Average & 1600 & 1860 & 2090 & \\
\hline
\end{tabular}

'For vertical (year) comparison. Means within columns followed by the same letter are not significantly different. (Duncan's multiple range test, $P<0.05$ ).

${ }^{2}$ For horizontal (time of clipping) comparison. The letters correspond to the three means within a year. Means having the same letter are not significantly different. (Duncan's multiple range test, $P<0.05$ ).

plants from June to October was significantly lower than that of October to February, while production resulting from cutting in August to December was not different from either. In 1978-79 mean yields from each of the three time periods were different.

Creeping bluestem makes most of its growth in the spring and summer (Yarlett and Roush 1970), and periodic clipping from June to October interrupted this growth. Forage yields were greater in the August to December and October to February periods because of the heavier yields accumulated by the initial harvest, which represented 60 and $77 \%$ of the total yield values for these respective periods shown in Table 1 . The initial growth of the June to October cutting period represented $37 \%$ of the total average $1,600 \mathrm{~kg} / \mathrm{ha}$.

Cutting creeping bluestem at $10 \mathrm{~cm}$ above the soil significantly reduced dry matter yields after 1977-78 (Table 2), but there was no significant drop in yield when plants were cut at $20 \mathrm{~cm}$. In 1976-77 and 1977-78 cutting plants at $10 \mathrm{~cm}$ resulted in higher yields, and this would be expected as more herbage was harvested when cut closer to the soil. In 1978-79 there was no difference in yield between height of cut treatments. The plant stands were thinning out at the $10-\mathrm{cm}$ height of cut, and tiller density (not in tables) was significantly less in the plots cut in June to October at the 10-cm level $\left(117\right.$ tillers $\left./ \mathrm{m}^{2}\right)$ as compared with the tiller density average from all other plots $\left(171\right.$ tillers $\left./ \mathrm{m}^{2}\right)$. The reduction in yield after 3 years of cutting at $10 \mathrm{~cm}$ in June, August, and October was
Table 2. Annual dry matter yield ( $\mathrm{kg} / \mathrm{ha}$ ) of creeping bluestem as affected by year and height of cut. Ona, Florida, 1976-79.

\begin{tabular}{llll}
\hline \hline & \multicolumn{3}{c}{ Height of cut (cm) } \\
\cline { 2 - 3 } Year & 10 & 20 & \\
\hline $1976-77$ & $2330^{\mathrm{a}}$ & $1340^{\mathrm{b}}$ & $\mathrm{a}, \mathrm{b}^{2}$ \\
$1977-78$ & $2100^{\mathrm{a}}$ & $1800^{\mathrm{a}}$ & $\mathrm{a}, \mathrm{b}$ \\
$1978-79$ & $1700^{\mathrm{b}}$ & $1800^{\mathrm{a}}$ & $\mathrm{a}, \mathrm{a}$ \\
\hline
\end{tabular}

'For vertical (year) comparison. Means within columns followed by the same letter are not significantly different (Duncan's multiple range test, $P<0.05$ ).

${ }^{2}$ For horizontal (height of cut) comparison. The letters correspond to the two means within a year. Means with the same letter are not significantly different. (Duncan's multiple range test, $P<0.05$ ).

probably due more to lower yield per tiller, rather than a significant loss of tillers.

\section{Forage Quality}

Crude protein was not significantly different $(P<0.05)$ in forage accumulated prior to the beginning of each of the three sampling periods (initial growth) (Table 3). Regrowth from July to August or September to October was significantly lower in crude protein content, than that harvested November to December or January to February. There were small changes in protein percentages found in the forage sampled within the June to October (5.0 to 5.7\%) or the October to February (4.5 to 6.8\%) clipping periods, although protein differences between these two periods were great. The August to December clipping period, which overlapped in former two periods, had the most dramatic changes in crude protein, which ranged from 4.8 to $7.7 \%$.

Since protein yield was influenced most by dry matter yield, protein yields were greatest for the forage accumulated from March to October $(70 \mathrm{~kg} / \mathrm{ha}$ ) (Table 4). Although ranchers using creeping bluestem during the winter would have more protein per hectare at the beginning of the season, little protein production could be expected from regrowth in November through February.

Percent IVOMD in forage was significantly lower in the March to October initial growth $(27.4 \%)$ as compared with forage accumulated in January to August ( $31.5 \%$ ), and the latter was lower than the initial November to June forage $(34.3 \%)$ (Table 5). These

Table 3. Crude protein (CP) on a dry matter basis in creeping bluestem as affected by time of initial growth and regrowth period. Ona, Florida, 1976-77 1977-78.

\begin{tabular}{|c|c|c|c|c|c|c|}
\hline \multirow[b]{3}{*}{ Clipping period } & \multicolumn{6}{|c|}{ Months when forage was produced } \\
\hline & \multicolumn{2}{|c|}{ Initial growth } & \multirow[b]{2}{*}{ Months } & \multicolumn{2}{|c|}{ Regrowth } & \multirow[b]{2}{*}{$\% \mathbf{C P}$} \\
\hline & Months & $\% \mathrm{CP}$ & & $\% \mathrm{CP}$ & Months & \\
\hline $\begin{array}{l}\text { June-Oct. } \\
\text { Aug.-Dec. } \\
\text { Oct.-Feb. }\end{array}$ & $\begin{array}{l}\text { Nov.-June } \\
\text { Jan.-Aug. } \\
\text { Mar.-Oct. }\end{array}$ & $\begin{array}{l}5.0^{\mathrm{a}} \mathrm{I} \\
4.8^{\mathrm{a}} \\
4.5^{\mathrm{a}}\end{array}$ & $\begin{array}{l}\text { July-Aug. } \\
\text { Sept.-Oct. } \\
\text { Nov.-Dec. }\end{array}$ & $\begin{array}{l}5.8^{\mathrm{b}} \\
5.8^{\mathrm{b}} \\
7.4^{\mathrm{a}}\end{array}$ & $\begin{array}{l}\text { Sept.-Oct. } \\
\text { Nov.-Dec. } \\
\text { Jan.-Feb. }\end{array}$ & $\begin{array}{l}5.7^{c} \mathrm{~b}, \mathrm{a}, \mathrm{a}^{2} \\
7.7^{\mathrm{a}} \mathrm{c}, \mathrm{b}, \mathrm{a} \\
6.8^{\mathrm{a}} \mathrm{c}, \mathrm{a}, \mathrm{b}\end{array}$ \\
\hline
\end{tabular}

'For vertical comparison. Means within columns followed by the same letter are not significantly different (Duncan's multiple range test, $P<0.05$ ).

2For horizontal comparison. Letters correspond to the three means on the same line. Means having the same letter are not significantly different (Duncan's multiple range test, $P<0.05)$.

Table 4. Yield (kg/ha) of crude protein (CP) from creeping bluestem as affected by time of initial growth and regrowth period. Ona, Florida, 1976-77 and 1977-78.

\begin{tabular}{|c|c|c|c|c|c|c|c|}
\hline \multirow[b]{3}{*}{ Clipping period } & \multicolumn{7}{|c|}{ Months when forage was produced } \\
\hline & \multicolumn{2}{|c|}{ Initial growth } & \multicolumn{5}{|c|}{ Regrowth } \\
\hline & Months & $\mathrm{CP}$ & Months & $\mathrm{CP}$ & Months & $\mathrm{CP}$ & \\
\hline $\begin{array}{l}\text { June-Oct. } \\
\text { Aug.-Dec. } \\
\text { Oct.-Feb. }\end{array}$ & $\begin{array}{l}\text { Nov.-June } \\
\text { Jan.-Aug. } \\
\text { Mar.-Oct. }\end{array}$ & $\begin{array}{l}30^{c_{1}} \\
50^{b} \\
70^{a}\end{array}$ & $\begin{array}{l}\text { July-Aug. } \\
\text { Sept.-Oct. } \\
\text { Nov.-Dec. }\end{array}$ & $\begin{array}{l}30^{\mathrm{a}} \\
30^{\mathrm{a}} \\
20^{\mathrm{b}}\end{array}$ & $\begin{array}{l}\text { Sept.-Oct } \\
\text { Nov.-Dec. } \\
\text { Jan.-Feb. }\end{array}$ & $\begin{array}{l}30^{\mathrm{a}} \\
20^{\mathrm{b}} \\
10^{\mathrm{c}}\end{array}$ & $\begin{array}{l}\mathrm{a}, \mathrm{a}, \mathrm{a}^{2} \\
\mathrm{a}, \mathrm{b}, \mathrm{c} \\
\mathrm{a}, \mathrm{b}, \mathrm{c}\end{array}$ \\
\hline
\end{tabular}

IFor vertical comparison. Means within columns followed by the same letter are not significantly different (Duncan's multiple range test, $P<0.05$ ).

2For horizontal comparison. Letters correspond to the three means on the same line. Means having the same letter are not significantly different (Duncan's multiple range test, $P<0.05$ ) 
Table 5. In vitro organic matter digestibility (IVOMD) in creeping bluestem as affected by time of initial growth and regrowth period. Ona, Florida. 197677 and 1977-78.

\begin{tabular}{|c|c|c|c|c|c|c|c|}
\hline \multirow[b]{3}{*}{ Clipping period } & \multicolumn{6}{|c|}{ Months when forage was produced } & \\
\hline & \multicolumn{2}{|c|}{ Initial growth } & \multicolumn{4}{|c|}{ Regrowth } & \\
\hline & Months & $\%$ IVOMD & Months & $\%$ IVOMD & Months & \% IVOMD & \\
\hline June-Oct. & Nov.-June & $34.3^{\mathrm{a}_{1}}$ & July-Aug. & $37.7^{\mathrm{a}}$ & Sept.-Oct. & $33.6^{\mathrm{b}}$ & $\mathrm{b}, \mathrm{a}, \mathrm{b}^{2}$ \\
\hline Aug.-Dec. & Jan.-Aug. & $31.5^{\mathrm{b}}$ & Sept.-Oct. & $33.8^{\mathrm{b}}$ & Nov.-Dec. & $35.7^{\mathrm{a}}$ & $\mathrm{c}, \mathrm{b}, \mathrm{a}$ \\
\hline Oct.-Feb. & Mar.-Oct. & $27.4^{\mathrm{c}}$ & Nov.-Dec. & $36.9^{\mathrm{a}}$ & Jan.-Feb. & $37.2^{\mathrm{a}}$ & $\mathrm{b}, \mathrm{a}, \mathrm{a}$ \\
\hline
\end{tabular}

'For vertical comparison. Means within columns followed by the same letter are not significantly different (Duncan's multiple range test, $P<0.05$ ).

${ }^{2}$ For horizontal comparison. Letters correspond to the three means on the same line. Means having the same letter are not significantly different (Duncan's multiple range test, $P<0.05$ )

Table 6. Yield (kg/ha) of digestible organic matter (DOM) in creeping bluestem as affected by time of initial growth and regrowth period. Ona, Florida, 1976-77 and 1977-78.

\begin{tabular}{|c|c|c|c|c|c|c|c|}
\hline \multirow[b]{3}{*}{ Clipping period } & \multicolumn{7}{|c|}{ Months when forage was produced } \\
\hline & \multicolumn{2}{|c|}{ Initial growth } & \multicolumn{4}{|c|}{ Regrowth } & \\
\hline & Month & DOM & Months & DOM & Months & DOM & \\
\hline $\begin{array}{l}\text { June-Oct. } \\
\text { Aug.-Dec. } \\
\text { Oct.-Fcb. }\end{array}$ & $\begin{array}{l}\text { Nov.-June } \\
\text { Jan.-Aug. } \\
\text { Mar.-Oct. }\end{array}$ & $\begin{array}{l}210^{\mathrm{c} 1} \\
350^{\mathrm{b}} \\
430^{\mathrm{a}}\end{array}$ & $\begin{array}{l}\text { July-Aug. } \\
\text { Sept.-Oct. } \\
\text { Nov.-Dec. }\end{array}$ & $\begin{array}{l}200^{\mathrm{a}} \\
170^{\mathrm{a}} \\
100^{\mathrm{b}}\end{array}$ & $\begin{array}{l}\text { Sept.-Oct. } \\
\text { Nov-Dec } \\
\text { Jan-Feb }\end{array}$ & $\begin{array}{r}170^{\mathrm{a}} \\
80^{\mathrm{b}} \\
30^{\mathrm{c}}\end{array}$ & $\begin{array}{l}a, a, b^{2} \\
a, b, c \\
a, b, c\end{array}$ \\
\hline
\end{tabular}

'For vertical comparison. Means within columns followed by the same letter are not significantly different (Duncan's multiple range test, $P<0.05$ ).

${ }^{2}$ For horizontal comparison. Letters correspond to the three means on the same line. Means having the same letter are not significantly different $(P<0.05)$.

differences in IVOMD were due to age of forage sampled. November to June initial forage was younger, spring growth as contrasted with senescent forage produced in the spring and summer and sampled in August or October. The IVOMD values were greater in regrowth than in their respective initial growths, and this was especially obvious in regrowth after the March to October initial, which increased from $27.4 \%$ initially to 36.9 and $37.2 \%$ in regrowth. Even the regrowth highest in IVOMD (July to August regrowth was $37.7 \%$ ) was apparently about $10 \%$ lower than the IVDMD values reported by Lewis et al. (1975) for bluestems grown during this period in southern Georgia.

Yield of digestible organic matter like protein yield was more of a function of dry matter yield than IVOMD\% and was greatest at the end of March to October initial growth period (Table 6). Regrowth from July to August resulted in greater DOM yields than November to December or January to February regrowth.

Percent NDF ranged from 79.1 to $82.0 \%$ and was not significantly different when comparisons were made among the initial growth cuttings (Table 7). NDF in regrowth from the June to October or August to December clipping period was not significantly different from the NDF of their respective initial periods. However, regrowth after the March to October initial period did drop significantly in NDF during each of the successive harvests. IVOM $\%$ was fairly closely associated with NDF\% with $r=0.70$. Leland et al (1976) reported cell wall constituents of unburned Andropogon gerardi (Vitman) and S. scoparium (Michx. Nash.) to be about $76 \%$ to $79 \%$, respectively, which is similar to those values in Table 7.

Percent ADF and ADL were affected by time of use (Table 8). Both ADF and ADL percentages were significantly higher in the October to February period than in the June to October period. The low IVOMD\% reflects the high percentage of seemingly

Table 8. Percent acid detergent fiber (ADF) and percent acid detergent lignin (ADL) in creeping bluestem as affected by time of use. Ona, Florida 1977-78.

\begin{tabular}{lccc}
\hline \hline & \multicolumn{3}{c}{ Clipping period } \\
\cline { 2 - 4 } & June to October & $\begin{array}{l}\text { August to } \\
\text { December }\end{array}$ & $\begin{array}{c}\text { October to } \\
\text { February }\end{array}$ \\
\hline ADF & $42.8^{\mathrm{a}_{1}}$ & $43.2^{\mathrm{a}}$ & $43.0^{\mathrm{a}}$ \\
ADL & $5.3^{\mathrm{b}}$ & $5.5^{\mathrm{b}}$ & $5.9^{\mathrm{a}}$ \\
\hline
\end{tabular}

'Means on the same line followed by the same letter are not significantly different. (Duncan's LSD, $\mathrm{K}=100$ ).

undigestible cellulose found in the ADF fraction. I eland et al (1976) reported lower cellulose values for $A$. gerardi and S. scoprium, which were $33 \%$ and $34 \%$, respectively. Lignin was $6 \%$ to $7 \%$, respectively, in these species. The ADL\% reported for creeping bluestem was not usually high so if lignin had a negative affect on

Table 7. Percent neutral detergent fiber (NDF) in creeping bluestem as affected by time of initial growth and regrowth period. Ona, Florida, $1977-78$.

\begin{tabular}{|c|c|c|c|c|c|c|c|}
\hline \multirow[b]{3}{*}{ Clipping period } & \multicolumn{6}{|c|}{ Months when forage was produced } & \\
\hline & \multicolumn{2}{|c|}{ Initial growth } & \multicolumn{4}{|c|}{ Regrowth } & \\
\hline & Months & NDF & Months & NDF & Months & NDF & \\
\hline June-Oct. & Nov.-June & $80.9^{a_{1}}$ & July-Aug. & $80.9^{\mathrm{a}}$ & Sept.-Oct. & $81.5^{\mathrm{a}}$ & $a, a, a^{2}$ \\
\hline Aug.-Dec. & Jan.-Aug. & $81.6^{\mathrm{a}}$ & Sept.-Oct. & $81.5^{\mathrm{a}}$ & Nov.-Dec. & $81.3^{\mathrm{a}}$ & $a, a, a$ \\
\hline Oct.-Feb. & Mar.-Oct. & $82.0^{\mathrm{a}}$ & Nov.-Dec. & $80.7^{\mathrm{a}}$ & Sept.-Oct. & $81.5^{\mathrm{a}}$ & $\mathrm{a}, \mathrm{a}, \mathrm{a}^{2}$ \\
\hline Aug.-Dec. & Jan.-Aug. & $81.6^{\mathrm{a}}$ & Sept.-Oct. & $81.5^{\mathrm{a}}$ & Nov.-Dec. & $81.3^{\mathrm{a}}$ & $\mathrm{a}, \mathrm{a}, \mathrm{a}$ \\
\hline Oct.-Feb. & Mar.-Oct. & $82.0^{\mathrm{a}}$ & Nov.-Dec. & $80.7^{\mathrm{a}}$ & Jan.-Feb. & $79.1^{\mathrm{a}}$ & $a, b, c$ \\
\hline
\end{tabular}

${ }^{1}$ For vertical comparison. Means within columns followed by the same letter are not significantly different (Duncan's multiple range test, $P<0.05$ ).

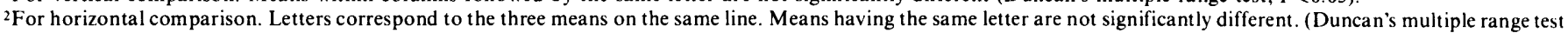
$P<0.05$ ). 
Table 9. Percent acid detergent fiber (ADF) and percent acid detergent lignin (ADL) in creeping bluestem forage as affected by initial harvest and regrowth. Ona, Florida. 1977-78.

\begin{tabular}{lll}
\hline \hline & \multicolumn{2}{c}{ Cell Fraction } \\
\cline { 2 - 3 } Harvest & ADF & ADL \\
\hline Initial & $44.1^{\mathrm{a}}$ & $6.2^{\mathrm{a}}$ \\
lst regrowth & $42.9^{\mathrm{b}}$ & $5.2^{\mathrm{b}}$ \\
2nd regrowth & $42.0^{\mathrm{c}}$ & $5.3^{\mathrm{b}}$ \\
\hline
\end{tabular}

'Means within columns followed by the same letter are not significantly different (Duncan's LSD, $\mathrm{K}=100$ )

digestibility, it was probably due to where the lignin was located in the cell rather than the quantity.

Both ADF and ADL percentages were higher in the initial harvest than in the two following 70-day regrowth periods (Table 9). This response was a reflection of older forage accumulated for the initial harvest. Regrowth ADF and ADL were lower than the initial harvest and were indicative of a better forage.

Although Yarlett and Roush (1970) had reported five vegetative tillers to one productive tiller on ungrazed, unburned creeping bluestem, the herbage in this study remained completely vegetative. The low protein and digestibility values were apparently due to low soil fertility and anatomical characteristics at the cellular level in leaf and sheath tissue.

These data indicate that intake, protein and digestible energy would be limiting factors for mature dry cows grazing creeping bluestem. Protein and digestibiliy of creeping bluestem does not appear to be greatly different from that reported for wiregrass (Kirk et al. 1974; Lewis et al. 1975). However, yield of creeping bluestem is greater than yield from wiregrass and this alone is justification for management to foster its dominance on Florida range. Continued research should deal with management that will improve grass quality.

\section{Conclusions}

Annual yields of creeping bluestem were highest when used from October to February as compared to use from June to October. Cutting creeping bluestem during June to October was detrimental to sustained yield, whereas cutting in August to December or October to February did not reduce yields after 3 years. Cutting at $10 \mathrm{~cm}$ resulted in a significant reduction in dry matter yield after 3 years as compared with cutting at $20 \mathrm{~cm}$ above the soil surface, which resulted in sustained yields.

Crude protein and IVOMD percentages were significantly greater in regrowth as compared to initial growth. Yield of protein and digestible organic matter was greatest in forage which had been accumulated from March to October. Although there were statistical differences in NDF, ADF or ADL percentages from creeping bluestem during the year, they were slight, and it is not anticipated that they would result in differences in livestock performance.

\section{Literature Cited}

Gallaher, R.N., C.O. Weldon, and F.C. Boswell. 1977. A semi-automated procedure for total nitrogen in plant soil samples. Soil Sci. Soc. Amer. Proc. 40:887-889.

Halls, L.D., R.H. Hughes, R.S. Rummell, and B.L. Southwell. 1964. Forage and cattle management in longleaf-slash pine forests. U.S.D.A. Farmers Bull. 2199.

Issac, R.A., and W.C. Johnson. 1976. Determination of total nitrogen in plant tissue using block digester. J. Ass. of Anal. Chem. 69:98-101.

Kirk, W.G., G.K. Davis, F.G. Martin, E.M. Hodges, and J.F. Easley. 1974. Effect of burning and mowing on the composition of pineland threeawn. J. Range Manage. 27:420-423.

Leland, J.A., L.H. Harbers, R.R. Scalles, C.E. Owensby, and E.F. Smith. 1976. Range burning and fertilizing related to nutritive value of bluestem grass. J. Range Manage. 29:306-308.

Lewis, C.E., R.S. Lowrey, W.G. Manson, and F.E. Knox. 1975. Seasonal trends in nutrients and cattle digestibility of forage on pine-wiregrass range. J. Anim. Sci. 41:208-212.

Moore, J.E., G.O. Mott, D.G. Dunham, R.W. Omer. 1961. Forage capacity in vitro OM digestion procedure. J. Anim. Sci. 31 (1) 231. Abstract No. 261.

Roush, R.D., and L.L. Yarlett. 1973. Creeping bluestem compared with four other native range grasses. $J$. Range Manage. 26:19-21.

Van Soest, P.J. 1963. Use of detergents in the analysis of fibrous feeds. II. A rapid method for the determination of fiber and lignin. J. Ass. Offic. Anal. Chem 56:829-835.

Van Soest, P.J., and R.H. Wine. 1967. Use of detergents in the analysis of fibrous feeds. IV. Methods for determination of plant cell walls. J. Ass. Offic. Anal. Chem. 50:50-55.

Yarlett, L.L. 1963. Some important and associated native grasses on central and south Florida ranges. J. Range Manage. 16:25-27.

Yarlett, L.L. 1965. Control of saw palmetto and recovery of native grasses. J. Range Manage. 18:344-345.

Yarlett, L.L., and R.D. Roush. 1970. Creeping bluestem (Andropogon stolonifer (Nash.)Hitchc.) J. Range Manage. 23:117-122. 